\title{
STRATEGI KOMUNIKASI PENYULUH AGAMA HINDU KANTOR KEMENTERIAN AGAMA KABUPATEN GIANYAR MELALUI MEDIA SOSIAL PADA MASA PANDEMI COVID-19
}

\author{
Putu Agus Andita a,1 \\ I Gusti Ngurah Sudiana a \\ I Wayan Sukabawa a
}

a Universitas Hindu Negeri I Gusti Bagus Sugriwa Denpasar

1 Corresponding Author, email: agusandita@yahoo.co.id (Andita)

\section{ARTICLE INFO}

\section{Article history:}

Received: 09-07-2021

Revised:12-08-2021

Accepted: 12-09-2021

Published: 30-09-2021

Keywords:

Strategi

komunikasi,

penyuluh, media

sosial, covid-19.
ABSTRACT

\begin{abstract}
Hindu religious instructors are people who carry out their duties as interpreters or provide counseling to Hindus. The extension worker conducts coaching by gathering the community at the village hall, or at the temple according to the target area. With the Covid-19 Pandemic, which forces people to stay at home and the rules issued by the government regarding the prohibition on gathering and gathering large numbers of people, of course, this makes it very difficult for extension workers to carry out their duties to provide guidance to Hindus in their target areas. each. The method used in this research is the interview method and also direct observation to the object of research as well as by studying the existing literature in the Hindu Guidance Section of the Ministry of Religion, Gianyar Regency. This research focuses on the strategies used by extension workers to continue carrying out their duties when the Covid-19 pandemic is hitting almost all countries in the world. The strategy used by the extension workers is through social media such as WhatsApp, Facebook, and through podcast broadcasts that are broadcast on the YouTube account of the Ministry of Religion of Gianyar Regency.
\end{abstract}

\section{PENDAHULUAN}

Penyuluh Agama Hindu merupakan seorang komunikator yang menyampaikan berbagai pesan keagamaan sedangkan umat Hindu adalah komunikan atau penerima pesan yang disampaikan oleh komunikator sehingga umat Hindu yang menerima pesan tersebut dapat menerima pesan dengan baik dan dapat melaksanakan serta mengamalkan pesan tersebut. Dalam menyampaikan sebuah pesan, seorang penyuluh agama harus menguasai kemampuan berkomunikasi yang baik. Tanpa memiliki kemampuan komunikasi yang baik maka penyampaian pesan yang akan disampaikan kepada audiens akan terganggu dan tidak maksimal

Agama memiliki peran yang sangat penting untuk pengendalian dan pedoman dalam pembentukan moral dan akhlak dalam kehidupan sebagai manusia. Ketika seseorang 
telah berpegang teguh pada agama maka dengan sendirinya seseorang akan mematuhi ajaran serta perintah Tuhan Yang Maha Esa serta akan menjauhi semua larangan yang telah diatur dalam kitab suci Veda. Strategi yang ditempuh untuk menghadirkan agama dalam lubuk hati masyarakat Hindu adalah salah satunya dengan mengadakan penyuluhan tentang ajaran agama. Ajaran-ajaran agama yang disampaikan bersumber dari kitab suci Veda yang telah diterjemahkan dengan kata-kata yang mudah dicerna namun tidak mengurangi maknanya malah sebaliknya memperkuat makna dari isi sloka dalam kitab Veda tersebut.

Pembinaan yang dilakukan oleh penyuluh agama Hindu bila dibandingkan dengan sebelum adanya pandemi Covid-19 dengan sekarang saat berlangsungnya pandemi Covid-19 yang melanda hampir semua negara di dunia tentu sangat berbeda karena bila dahulu penyuluh agama Hindu memberikan penyuluhan dengan mengumpulkan orang di Balai Masyarakat, Pura atau tenpat lainnya maka, semenjak merebaknya virus Covid-19 ini pembinaan umat menjadi terganggu karena adanya peraturan dari pemerintah Republik Indonesia yang melarang berkumpul dengan jumlah orang yang banyak sehingga sangat menyulitkan para penyuluh agama Hindu untuk melaksanakan kewajibannya.

Realita ini membuat para penyuluh agama Hindu dituntut untuk kreatif dalam melaksanakan kewajibannya. Media sosial menjadi pilihan dalam menyampaikan pesanpesan dharma kepada umat Hindu yang tersebar di Kabupaten Gianyar. Namun pemanfaatan media sosial ini tentu tidak serta merta dapat menyelesaikan permasalahan yang dihadapi para penyuluh agama Hindu karena tidak semua kalangan masyarakat yang beragama Hindu di Kabupaten Gianyar melek akan tekhnologi khususnya para lansia yang tinggal di daerah pinggiran Kota Gianyar. Virus Covid-19 ini menyebar begitu cepat dan membahayakan sehingga membuat pemerintah mengeluarkan kebijakan untuk tidak melakukan aktifitas di luar rumah dan melakukan semua kegiatan dari rumah mulai dari bekerja, ibadah, sekolah dan aktifitas lainnya. Semua kehidupan yang dulunya berjalan normal dengan mobilitas orang dan juga barang serta jasa yang sangat tinggi dan sibuk sepanjang hari secara mendadak berhenti total oleh penyebaran virus ini bahkan sampai banyak Negara harus memberlakukan lock down atau menutup negaranya dari orang luar untuk memutus mata rantai penularan Covid-19 ini.

Kantor Kementerian Agama Kabupaten Gianyar memiliki 12 orang tenaga Penyuluh dengan status Pegawai Negeri Sipil dan 65 orang tenaga Penyuluh dengan status Non Pegawai Negeri Sipil. Dengan jumlah penyuluh tersebut dibagi ke dalam tujuh kabupaten yang tersebar di Kabupaten Gianyar. Dengan adanya pandemi Covid-19 ini tentu sangat mempengaruhi gerak langkah para penyuluh agama Hindu dalam menjalankan Swadharmanya sebagai penyebar ajaran Dharma. Di samping keadaan pandemi ini, tingkat pendidikan para penyuluh agama Hindu pada Kantor Kementerian Agama Kabupaten Gianyar juga berbeda dari tingkat Sarjana Muda (BA) hingga jenjang Strata dua (S2) sehingga dengan adanya pandemi ini maka kemampuan penyuluh dalam menyampaikan ajaran Dharma kepada masyarakat akan sangat diuji sesuai dengan kemampuannya.

Realitas mengenai tata cara pembinaan yang dilakukan oleh penyuluh agama Hindu di Kantor Kementerian Agama Kabupaten Gianyar menarik perhatian penulis untuk mengkaji dan meneliti secara ilmiah dan mendalam dari sudut pandang Ilmu Komunikasi Hindu. Oleh sebab itu peneliti mencoba meneliti dan menulisnya dengan judul "Strategi Komunikasi Penyuluh Agama Hindu Kantor Kementerian Agama Kabupaten Gianyar Melalui Media Sosial pada Masa Pandemi Covid-19". 


\section{METODE PENELITIAN}

Penelitian ini mengambil tempat di Kantor Kementerian Agama Kabupaten Gianyar yang terletak di jalan Kepundung No. 8 Kota Gianyar Bali. Kemenag Kabuapten Gianyar saat ini sedang gencar membangun Zona Integritas dan juga WBBM untuk menuju WBK. Namun karena adanya Pandemi Covid-19 ini maka berbagai layanan menjadi terganggu sehingga tidak berjalan maksimal khususnya bagian penyuluhan agama Hindu.

Penelitian ini menggunakan metode wawancara langsung kapada para penyuluh serta pemegang kebijakan pada kantor Kemenag Kabupaten Gianyar serta dengan melakukan studi kepustakaan terkait dengan kegianatn yang telah dilakukan oleh para penyuluh Agama Hindu sebelum masa Pandemi dan saat masa Pandemi Covid-19.

\section{HASIL DAN PEMBAHASAN}

\section{Strategi Komunikasi Penyuluh Agama Hindu Kantor Kementerian Agama Kabupaten Gianyar}

Tata cara atau metode adalah cara yang dapat digunakan untuk mengimplementasikan rencana yang sudah disusun dalam bentuk kegiatan nyata dan praktis untuk mencapai tujuan pembelajaran (Zulkifli, 2011:6). Berdasarkan pengertian tersebut dapat kita uraikan bahwa tata cara atau metode adalah sebuah cara yang ditempuh untuk mewujudkan sesuatu. Demikian pula dengan para Penyuluh pada Kantor Kementerian Agama Kabupaten Gianyar sebelum melaksanakan tugas penyuluhan kepada masyarakat di wilayah binaannya, penyuluh akan menentukan tata cara atau metode yang akan digunakan untuk menyampaikan materi keagamaan Hindu.

Penyuluh Agama Hindu pada Kantor Kementerian Agama Kabupaten Gianyar melaksanakan tugas penyuluhan dengan cara tatap muka langsung terhadap masyarakat di wilayah binaannya masing-masing. Dalam satu minggu minimal dua kali penyuluh akan turun ke lapangan wilayah binaannya untuk menyampaikan materi tentang keagamaan Hindu. Tempat untuk melaksanakan penyuluhan ini biasanya dilaksanakan di balai desa atau balai banjar setempat.

Berdasarkan wawancara yang dilakukan dengan Koordinator Penyuluh Agama Hindu Kemenag Kabupaten Gianyar, disampaikan bahwa sebelum merebaknya wabah virus Covid19 ini para penyuluh sangat sering melakukan tatap muka langsung kepada masyarakat karena dengan bertatap muka langsung akan terbangun suasana yang lebih akrab dan juga rasa dalam menyampaikan pesan agama itu akan menjadi lebih indah bila bertemu secara langsung dengan masyarakat binaan. Seperti disampaikan oleh Ibu Ni Made Samar, S.Ag.,M.Pd.H :

"Proses penyuluhan sebelum masa Pandemi Covid-19 biasa dilakukan dengan mengadakan pertemuan langsung dengan masyarakat di wilayah binaannya. Tatap muka secara langsung penting dilakukan untuk menjalin komunikasi yang lebih intens antara warga masyarakat binaan dengan para penyuluh agama Hindu. Pertemuan dengan masyarakat wilayah binaan biasanya dilakukan di balai desa atau di tempat-tempat yang ditentukan oleh prajuru desa tempat dilaksanakannya proses penyuluhan". (wawancara tanggal 17 Mei 2021).

Tata cara melakukan penyuluhan saat mulai mewabahnya virus Covid-19 ini tentu sangat berpengaruh terhadap gerak langkah para penyuluh dalam melaksanakan penyuluhan. Penyebaran virus yang begitu cepat dan berbahaya memaksa pemerintah untuk mengeluarkan larangan untuk berkumpul dan juga melakukan aktifitas yang dapat menimbulkan kerumunan.

Berdasarkan hal tersebut tentu ini memberatkan tugas penyuluh dan kepala Kantor 
Kementerian Agama Kabupaten Gianyar tentu memiliki kebijakan terkait permasalahan ini seperti yang disampaikan oleh Kepala Kantor Kemenag Kabupaten Gianyar bahwa kebijakan tentang penyuluhan berasal dari pusat kemudian turun ke Kanwil Kementerian Agama Provinsi Bali selanjutnya dilaksanakan oleh Kantor Kemenag di kabupaten maupun kota di Bali. Untuk penyuluh tetap melaksanakan tugasnya memberikan pendampingan kepada masyarakat yang terdampak dengan adanya pembatasan sosial ini. Penyuluh dapat melaksanakan penyuluhan dengan memanfaatkan media sosial dan juga aplikasi yang ada pada smartphone untuk tetap berkomunikasi dengan masyarakat di wilayah binaannya masing-masing.

Kebijakan tersebut kemudian dilaksanakan oleh para penyuluh dengan melakukan sosialisasi kepada masyarakat binaannya agar mereka membuat group-group percakapan di media sosial seperti WhatsAp, Facebook serta aplikasi lainnya yang memungkinkan penyuluh untuk menyampaikan pesan keagamaan serta penguatan-penguatan mental kepada masyarakat yang terdampak Pandemi Covid-19 tersebut.

Melaksanakan proses penyuluhan tentu diawali dengan beberapa persiapan sebelum melaksanakan proses penyuluhan. Persiapan tersebut meliputi melakukan survey lapangan untuk mengetahui berbagai hal yang berkaitan dengan permasalahan yang dihadapi warga masyarakat pada wilayah binaannya. Penyebaran Covid-19 sangat mempengaruhi tatanan kehidupan masyarakat yang sebelumnya bebas untuk melakukan kegiatan dan berkumpul sekarang menjadi serba terbatas karena adanya pembatasan sosial dan juga pembatasan kegiatan masyarakat. Hal ini sangat menghambat penyuluh dalam melaksanakan tugasnya memberikan penyuluhan kepada masyarakat dan juga pelayanan lainnya seperti membaca Doa dan juga permintaan Dharma Wacana oleh masyarakat. Atas dasar tersebut, Kepala Kantor Kementerian Agama Kabupaten Gianyar mengeluarkan kebijakan yang telah dikoordinasikan dengan Kantor Wilayah Kementerian Agama Provinsi Bali bahwa saat masa Pandemi Covid-19 seperti sekarang ini penyuluhan harus tetap berjalan sesuai dengan tugas yang telah dibebankan oleh pimpinan kepada para penyuluh khususnya penyuluh Agama Hindu.

Berdasarkan hasil wawancara dengan Kepala Kantor Kementerian Agama Kabupaten Gianyar Bapak Ida Bagus Made Oka Yusa Manuaba menyatakan bahwa :

"Masalah ini tentu tidak boleh menghambat para penyuluh dalam melaksanakan tugasnya. Dengan kemajuan tekhnologi seperti sekarang ini yang sudah semakin maju maka penyuluhan tidak harus dengan melakukan tatap muka langsung dengan para masyarakat sasaran binaan. Para penyuluh dapat memanfaatkan jejaring media sosial untuk melaksanakan penyuluhan. Kita di Kemenag Kabupaten Gianyar juga sekarang telah membuat inovasi berupa program Podcast dan juga melalui Aplikasi Pinter Kemenag. Penyuluh dapat memanfaatkan inovasi ini untuk membantu kelancaran tugasnya". (wawancara tanggal 11 Juni 2021).

Setelah itu terlaksana kemudian penyuluh membuat perencanaan jangka pendek hingga panjang untuk menentukan materi yang akan disampaikan kepada warga masyarakat. Penyusunan materi tentu disesuaikan dengan undangan yang disampaikan oleh warga masyarakat setelahnya penyuluh akan menyusun materi tentu penyuluh mencari dasar hukumnya pada kitab suci Hindu kemudian dielaborasi oleh penyuluh disesuaikan dengan perkembangan jaman sehingga para peserta tidak merasa bosan dengan materi yang disampaikan seperti diungkapkan oleh salah 
satu penyuluh PNS Kemenag Kabupaten Gianyar Drs. I Ketut Biru, M.Si yang menyampaikan bahwa :

Penyusunan materi penyuluhan saat pandemi seperti sekarang ini tentu berbeda dengan penyusunan materi saat sebelum merebaknya virus Corona ini. Saat ini kita sebagai penyuluh harus sangat berhati-hati dalam menyusun materi di tengah perekonomian masyarakat yang tidak menentu.Jangan sampai materi yang kita sampaikan membuat ada peserta yang merasa tidak nyaman.Saat seperti ini, materi yang disampaikan hendaknya yang berkaitan dengan pemberdayaan ekonomi umat dan juga penguatan-penguatan mental dalam menghadapi masa sulit ini. (wawancara 17 Mei 2021)

Menurut keterangan dari Bapak Ketut Biru tersebut, penyusunan materi saat masa Pandemi Covid-19 ini tentu berbeda dengan saat sebelum mewabahnya Pandemi ini, saat ini materi yang disampaikan harus sesuai dengan kebutuhan masyarakat terutama dalam hal ekonomi umat dan juga penguatan-penguatan mental kepada masyarakat karena saat ini masyarakat cendrung kesulitan dalam ekonomi. Disinilah peran penyuluh untuk memberikan penguatan sangat penting.

Proses penyuluhan saat ini dilakukan tentu mengacu kepada kebijakan kepala kantor bahwa penyuluh harus kreatif dan berinovasi untuk memberikan pelayanan kepada umat Hindu melalui dunia elektronik yaitu lewat media sosial dan aplikasi percakapan untuk meminimalkan bertemu dengan orang banyak sehingga tidak melanggar protokol kesehatan yang telah ditetapkan oleh pemerintah.

Kementerian agama juga telah membuat inovasi untuk mendukung kebijakan ini dengan meluncurkan program podcast dan juga aplikasi PINTER yang di dalamnya memuat tiga layanan online yang dapat dimanfaatkan oleh masyarakat guna meminimalkan tatap muka serta dapat dimanfaatkan oleh para penyuluh untuk menyampaikan pesan dharma kepada umat Hindu seperti diungkapkan oleh Kasubag Tata Usaha Kemenag Kabupaten Gianyar AA. Istri Rai Anggraeni yang menyatakan bahwa :

Aplikasi PINTER dan Podcast ini memang dibuat sebagai jawaban atas kondisi sekarang saat mewabahnya Virus Corona yang mengharuskan kita untuk mebatasi acara yang dapat menimbulkan kerumunan. Dengan adanya aplikasi ini tentu masyarakat tidak perlu jauh-jauh datang ke Kantor Kementerian Agama Kabupaten Gianyar untuk mendapatkan layanan.Cukup dengan membuka link yang telah disosialisasikan melalui akun youtube, akun Facebook Kemenag Gianyar dan juga melalui Pelayanan Terpadu Satu Pintu yang selalu mensosialisasikan aplikasi ini guna mendapat respon dari masyarakat. (wawancara tanggal 16 Juni 2021)

Pernyataan informan tersebut dapat disimpulkan bahwa keberadaan aplikasi PINTER dan Program Podcast ini menjadi media yang sangat membantu para penyuluh untuk melakukan tugasnya tanpa harus mengadakan tatap muka dengan para masyarakat binaannya. Dengan aplikasi ini pemohon layanan cukup membuka link PINTER Kementerian Agama Gianyar maka pemohon Layanan sudah dapat mendapatkan layanan secara cepat dan juga aman karena tidak melakukan tatap langsung. Strategi komunikasi yang dilakukan Penyuluh PNS Kantor Kementerian Agama Kabupaten Gianyar melalui media sosial ini sangat efektif karena dengan kondisi Pandemi Covid-19 ini yang melarang aktifitas berkumpul maka strategi komunikasi melalui media sosial ini sangat membantu penyuluh untuk tetap melaksanakan tugasnya memberikan penyuluhan kepada masyarakat di wilayah binaannya masing-masing.

Podcast Kantor Kementerian Agama Kabupaten Gianyar juga berperan aktif 
mensosialisasikan program-program yang dilaksanakan oleh para penyuluh agama Hindu. Secara bergiliran setiap tiga kali dalam seminggu para penyuluh melakukan rekaman podcast untuk disiarkan pada chanel youtube kemenag gianyar.

\section{Gambar 1}

Proses Rekaman Podcast Oleh Penyuluh Agama Hindu

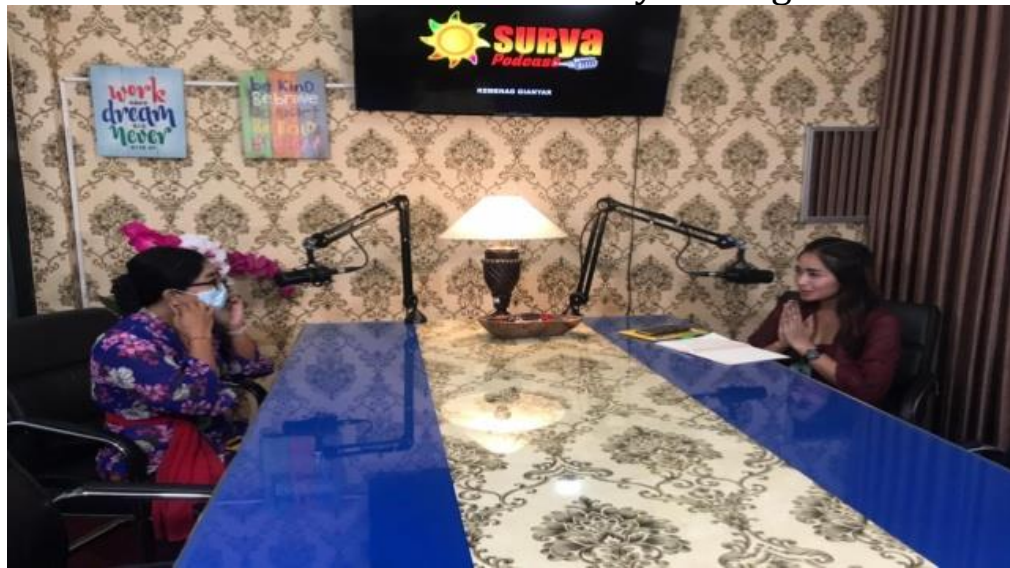

Dokumentasi Putu Agus Andita 27 Mei 2021

Proses penyuluhan agama Hindu juga dilaksanakan melalui siaran radio yang ada di Kota Gianyar. Namun penyuluhan lewat radio tentu tidak bisa dilaksanakan setiap hari tetapi menunggu undangan dari pihak radio untuk mengisi slot waktu yang disedikan oleh pihak manajemen radio. Hal ini seperti diungkapkan oleh penyuluh Bapak I Made Irawan yang menyatakan :

"Kalau untuk penyuluhan melalui stasiun radio yang ada di Kota Gianyar tentu kita tidak bisa sering-sering melakuknnya karena memang tergantung daru permintaan dari pihak stasiun radio tersebut. Bisa seminggu sekali, atau bisa juga terkadang sebulan dua atau tiga kali tetapi kita selalu siap bila diminta untuk melakukan bimbingan penyuluhan melalui media radio ini. Media ini tentu sangat membantu penyuluh dalam melaksanakan tugasnya apalagi saat masa pandemi ini yang diharuskan untuk selalu menjaga jarak dan menghindari kerumunan kita angat terbantu sekali karena masyarakat dapat menyimak siaran radio dari tampatnya masing-masing". (wawancara tanggal 17 Mei 2021).

Gambar 2

Penyuluhan Melalui Radio

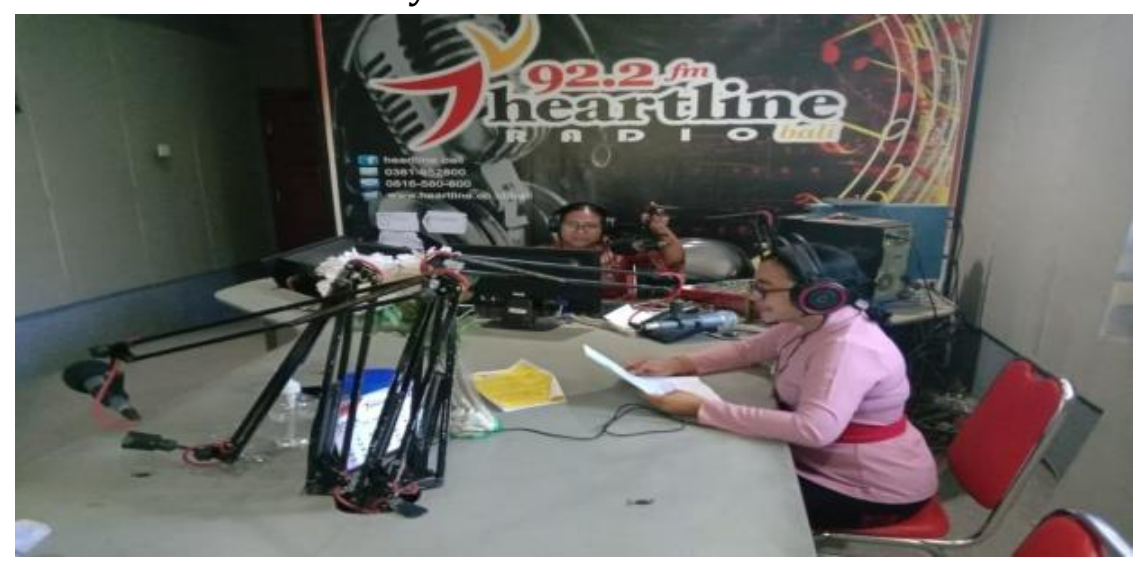

Dokumentasi Putu Agus Andita 19 Mei 2021 


\section{SIMPULAN}

Berdasarkan uraian pada penjelasan pada karya tulis diatas maka kesimpulannya adalah sebagai berikut :

1. Tata cara penyuluhan yang dilakukan oleh Penyuluh Agama Hindu pada Kantor Kementerian Agama Kabupaten Gianyar sebelum adanya Pandemi Covid-19 ini adalah dengan cara penyuluh langsung turun ke wilayah binaannya masing-masing guna melakukan pertemuan tatap muka langsung sehingga terbangun suasana yang hangat dan terjadi interaksi timbal balik dari masyarakat terhadap materi yang disampaikan oleh penyuluh tersebut. Sedangkan saat masa Pandemi Covid-19 ini tata cara penyuluhan yang dilakukan oleh para penyuluh pada Kantor Kementerian Agama Kabupaten Gianyar adalah melalui Media Sosail dengan memanfaatkan Aplikasi WhatsApp, Facebook, Instagram, Podcast, dan juga aplikasi PINTER Kemenag Kabupaten Gianyar.

2. Dalam melaksanakan proses penyuluhan tentu diawali dengan perencanaan dan juga penyusunan materi yang akan disampaikan kepada para masayrakat binaan. Sebelum melaksanakan penyuluhan, para penyuluh akan melakukan pemetaan dan juga pendataan berkaitan dengan kondisi daerah masyarakat binaannya kemudian dilanjutkan dengan penyusunan materi yang disesuaikan dengan kondisi masyarakat dan juga generasi muda. Penyuluh akan mengutip materi dari kitab suci Hindu kemudian mengelaborasi dengan perkembangan jaman dan tekhnologi sehingga materi yang disampaikan tidak terkesan membosankan.

3. Strategi komunikasi yang digunakan oleh para penyuluh di Kementerian Agama Kabupaten Gianyar adalah dengan memanfaatkan aplikasi yang tersedia pada Smathphone antara lain WhatsApp, Instagram, Facebook, Podcast Kemenag
Kabupaten Gianyar, dan juga melalui Aplikasi PINTER Kemenag Kabupaten Gianyar. Para penyuluh sangat terbantu dengan adanya aplikasi ini sehingga mereka tetap dapat melaksanakan tugasnya di tengam masamasa sulit seperti sekarang ini.

\section{SARAN}

Saran atau sumbangsih pikiran, ide atau gagasan yang bertujuan untuk memberikan arahan kan segala kekurangan yang ada. Maka berasarkan uraian dari hasil penelitian di atas dikemukakan beberapa saran yang ditujukan kepada :

1. Pimpinan Kantor Kementerian Agama Kabupaten Gianyar, berdasarkan temuan pada penelitian ini, diharapkan kepada para pengambil kebijakan pada Kantor Kementerian Agama agar lebih memperhatikan Fasilitas yang diberikan kepada para penyuluh. Fasilitas adalah hal sangat penting untuk menjaga Integritas dan juga Kinerja para Penyuluh Agama Hindu. Dengan Fasilitas yang lebih lengkap dan memadai maka penyuluh akan lebih semangat dalam berinovasi dan juga menjalankan tugasnya sebagai pelayan umat Hindu khususnya di kabupaten Gianyar.

2. Penyuluh Agama Hindu Kantor Kementerian Agama Kabupaten, agar lebih meningkatkan kualitas diri dalam melakukan penyuluhan terlebih saat masa Pandemi Covid-19 ini sehingga masyarakat akan lebih mengharapkan kehadiran para penyuluh. Penyuluh harus lebih berinovasi dalam menentukan tata cara penyuluhan sehingga tidak monoton dan juga terkesan itu-itu saja. Tampilan penyuluhan harus dibuat lebih menarik lagi sehingga masyarakat akan lebih antusias dalam mengikuti penyuluhan. Kemampuan dalam berkomunikasi juga harus lebih 
ditingkatkan guna mengangkat citra penyuluh untuk menjadi lebih baik lagi.

\section{DAFTAR PUSTAKA}

AA. Putra Dwipayana (2020), Pemanfaatan Media Informasi Online Sebagai Strategi Penyuluh Agama Hindu di Masa Pandemi Covid-19.

Effendi, O.U.2011. Ilmu Komunikasi : Teori dan Prakteknya. Bandung : Remaja Rosdakarya.

Gunadha, Ida Bagus. (2013). Panca Sradha Lima Prinsip Keimanan Hindu Indonesia. Denpasar: Widya Dharma

Sugiyono. 2016. Metode Penelitian Pendidikan, Pendekatan Kuantitatif, Kualitatif, Dan R\&D. Bandung : Alfabeta.

I Wayan Sukabawa, Strategi PHDI Meningkatkan Sradha dan Bhakti Umat Hindu di Kota Palangka Raya Kalimantan Tengah. Jurnal Penelitian Vidya Samhita. 